\title{
STATUS, PERSPECTIVES AND SPECIFIC FEATURES OF WIND ENERGY IN 2011
}

\author{
E. Zlomušica* \\ University „Džemal Bijedić“" of Mostar \\ Maršala Tita, 88104 Mostar, B\&H
}

\begin{abstract}
Electricity generation from wind energy is more than 100 years old. Windfarms represent a significant source of electricity today. Their size and power continually increase, their operating performances are improved, as well as the characteristics of the connection and operation in the net, the offshore market is being developed and so on. There are various estimates, based on specific goals and possibilities that suggest their more significant role in the future. However, to achieve these goals it is necessary to provide a number of assumptions. This paper reviews the current state of and prospects for electricity generation from wind farms in the world with some of their specific features.
\end{abstract}

Keywords: wind energy, status, perspectives, specific features.

\section{INTRODUCTION}

The first attempts at generation of electrical energy from wind date back to the end of $19^{\text {th }}$ and beginning of $20^{\text {th }}$ century (James Blyth, Scotland, Charles F. Brush, Cleveland, USA, Poul la Cour, Denmark, etc.).

This was followed by a long time period with a huge number of different construction designs of water turbines. Amongst others, it was noted that in 1940 in Vermont (USA) air-profile blades were introduced in the construction of wind turbines (Smith-Puntam).

Big energy crises in 1970s placed the wind turbines more in the spotlight. A period with different construction solutions (single-blade, doubleblade, three-bladed, horizontal, vertical and other wind turbines) ensued. An aspiration was toward big dimensions and powers. Some of those solutions were more, other were less successful. Some of them were very expensive. In any case, the construction technology did not sufficiently go hand in hand with the constructive elements design.

EU was the first one to recognise the possibilities and the importance of renewable energy sources, the energy of the wind among them. Thus, EU was the first to set its goals in mid 1990s. Until now, these goals have been fulfilled every time by the set deadlines. On the other hand, the goals set at the beginning of the new millennium, [1], have been a subject of intensive discussions for a number of years already.

\footnotetext{
*Corresponding author: elvir.zlomusica@unmo.ba
}

Wind farms have seen their extreme growth and development since the signing of the Kyoto protocol (1997). In some countries and/or their parts this growth is comparable even with the development of mobile telephony, Figure 1.

At that time, Denmark set up an example of its own. One can say that Denmark found itself, at the right time at the right place". So, even today Danish companies are the biggest producers of wind turbines in the world. As an example, $21 \%$ of the electric energy supply in Denmark comes from the energy of the wind (in January 2007, 38\% or, according to the information from the system operator web site, in the morning of 13 September 2011, the wind turbines in Denmark generated $64 \%$ of total electric energy production).

Amond other countries, one should especially mention Germany, which, in 2008 had the biggest number of installed capacities in the world. Namely, in these countries, the space resources for installing the wind parks are almost completely exhausted. They are setting their future goals on the basis of repowering and opening of offshore markets.

\section{WIND FARM MARKET}

As of the year 2010 the total of 194390 MW were installed throughout the world, [2]. In 2010 the new capacities of 47.3 billion $€$ were installed. For the sake of comparison, in 2006 there were 74052 MW installed. So, in four years the capacities have more than doubled. Thus, all realistic expectations 
were surpassed. If we look at the values from 10 years ago (18 $000 \mathrm{MW}$ in the year 2000), the results are even more significant.

Table 1. Top 10 countries by installed capacities

\begin{tabular}{|r|r|r|}
\hline \multicolumn{1}{|c|}{ Country } & \multicolumn{1}{c|}{ MW } & \multicolumn{1}{c|}{$\%$} \\
\hline China & 42,287 & 21,8 \\
\hline USA & 40,180 & 20,7 \\
\hline Germany & 27,214 & 14,0 \\
\hline Spain & 20,676 & 10,6 \\
\hline India & 13,065 & 6,7 \\
\hline Italy & 5,797 & 3,0 \\
\hline France & 5,660 & 2,9 \\
\hline UK & 5,204 & 2,7 \\
\hline Canada & 4,009 & 2,1 \\
\hline Denmark & 3,752 & 1,9 \\
\hline Other & 26,546 & 13,7 \\
\hline Total Top 10 & 167,844 & 86,3 \\
\hline Total & 194,390 & 100 \\
\hline
\end{tabular}

By the end of 2002, 75\% installed capacities were in Europe, $15 \%$ in USA, and $10 \%$ in the rest of the world. In 2006 the data was as follows: $65 \%$ in Europe, $15.6 \%$ in USA, and $19.4 \%$ in the rest of the world (with a significant share of India with 6270 MW or $8.4 \%$ and China with $2604 \mathrm{MW}$ or 3.5). Therefore, that proportion has changed and keeps changing, so that in 2010 in Europe there was $44.2 \%$, in Asia 30.1\% (21.8\% in China, 6.7\% in India), in USA $20.7 \%$ installed capacities of total installed capacities in the world.

There are 20 countries in the world already, of which in Europe as many as 14 countries, with more than $1000 \mathrm{MW}$ of installed capacities. Five years ago this was 13 countries, of which 8 in Europe. As far as Europe is concerned, Germany and Spain have more than $50 \%$ of total installed capacities, [3]. In 2008 , the biggest number of capacity was added in the wind energy for the first time in EU.

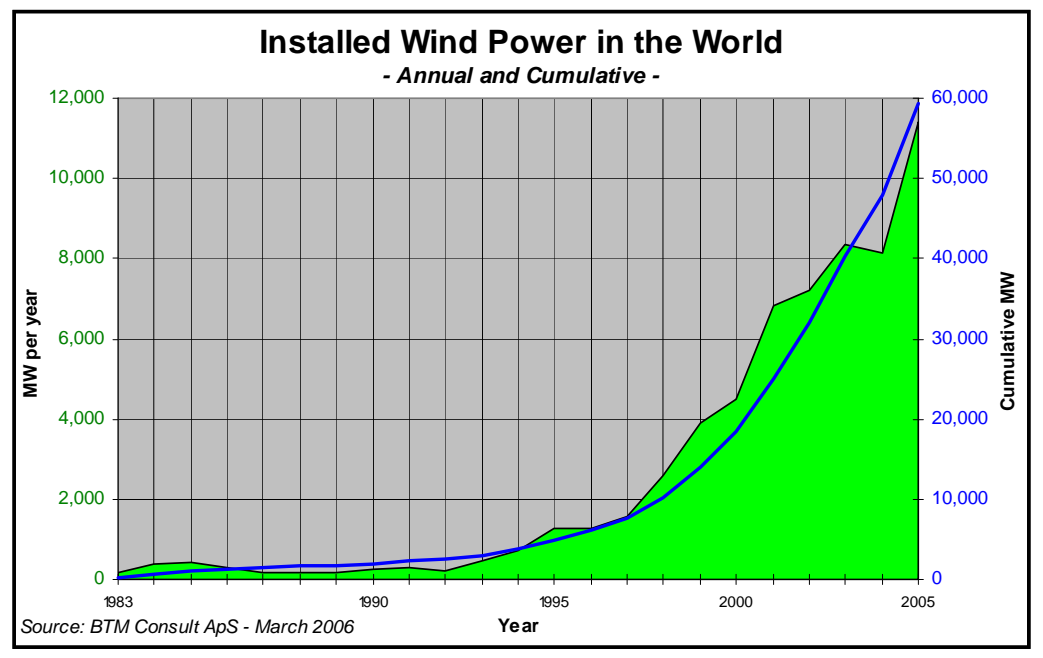

Figure 1. Growth of installed capacities

Thanks to the ,incredible" $16500 \mathrm{MW}$ added in 2010, a few years before the estimates were made, China took over the first position by installed capacities from the USA, and the USA took over that place from Germany in 2008. Also, China has considerable plans in the next period, [4,5]. Table 1 shows the capacities in top 10 countries in the world (with most capacities), [6]. One can see from the table that Europe still has the most capacities installed (35.1\% of top 10 countries).

Despite these, more than excellent total results, it is noteworthy that $7 \%$ less capacities (35 $802 \mathrm{MW}$ or $€ 47,3$ billion) compared to the previous year were installed in 2010, which was the first time that less capacities were installed. This is explained by the influence of the global financial crisis, Figure 2.
Of total capacities added in 2010, China installed $46.1 \%$. Thus, China is advancing fast toward its goal: $100 \mathrm{GW}$ by the year 2020 [4]. USA added $14.3 \%$ in the year 2010 , which is almost a $50 \%$ decline compared to the previous year. They are followed by India $6.0 \%$ and Spain with $4.2 \%$, with the same percentage as in Spain installed in Germany too. Also, in 2010 China became the world's largest producer of wind turbines.

Europe has also seen an increase of $50 \%$ of offshore markets. This is mainly related to UK, Denmark and Belgium, [3]. EU has set its goals for RES by 2020. Specific values have been set for each EU member country. As for the energy of the wind, the estimates and forecasts are both different and optimistic (180 GW - $230 \mathrm{GW})$. This implies crea- 
tion of over 2000000 new jobs in this sector by 2020. These optimistic goals can be achieved by intensifying offshore markets and by opening offshore parks, the implementation of which is currently below expectations.

Fig. 3 shows 20 countries that use the wind energy for electricity generation the most. As previously said, Denmark is in the first place, and is followed by other European countries (Portugal,
Spain, Ireland, Germany, etc.), while the first nonEuropean country taking the tenth place is India. According to the diagram in Fig. 3, and according to the other available data, if we analyse shares of production technologies for electricity production, the proportion of the use of wind energy in the world is $1.9 \%$.

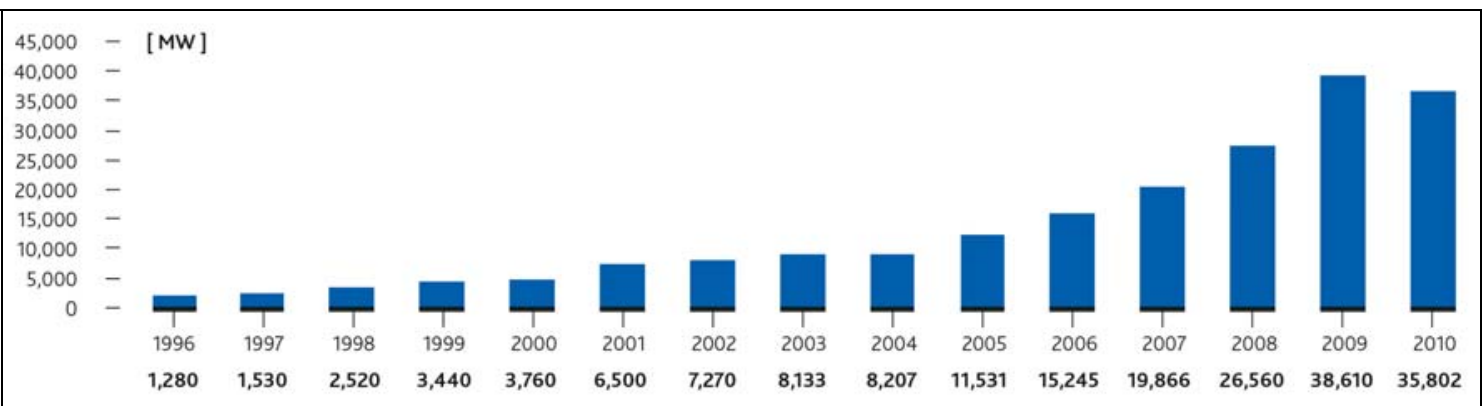

Figure 2. Capacities installed in the world on the annual basis 1996 - 2010, [6]

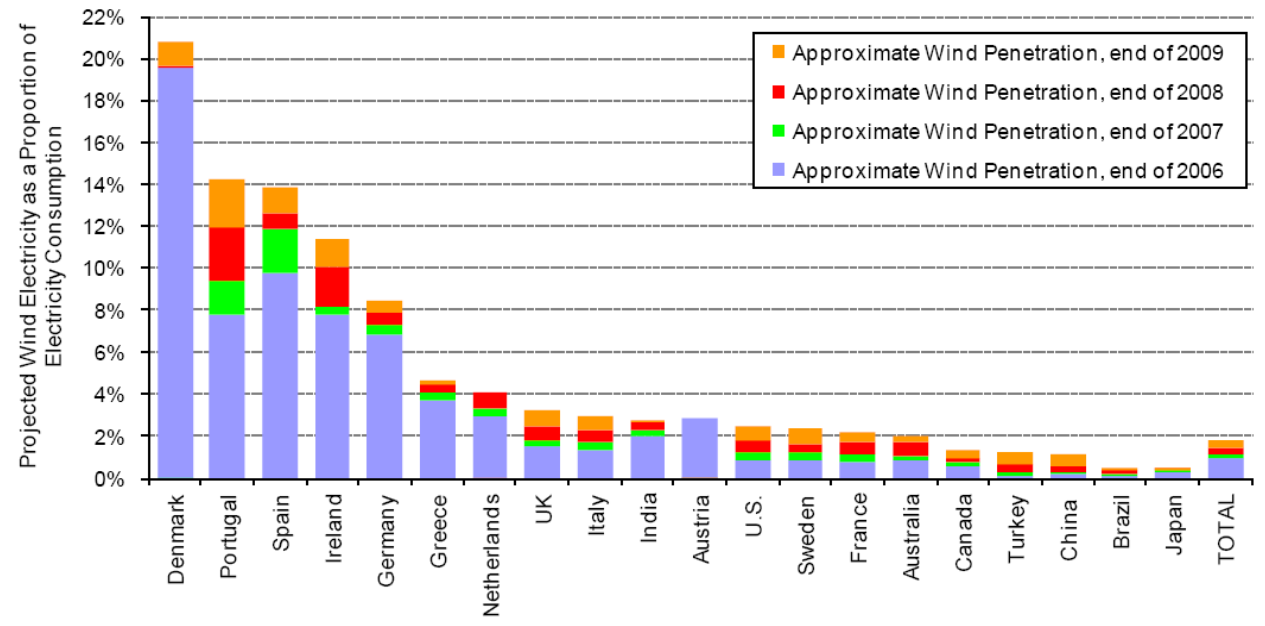

Source: Berkeley Lab estimates based on data from BTM Consult and elsewhere

Figure 3. Top 20 countries by using the wind energy

\section{TRENDS IN THE DEVELOPMENT OF THE INDUSTRY OF WIND TURBINES}

With the development of technology, technical characteristics of wind turbines and wind parks have significantly improved.

In the past few years new equipment manufacturers have emerged in the market, they are mostly big multi-national companies (General Electric, Siemens, Mitsubishi, etc.), and due to these companies, together with the „old“ companies, there has been an intensive improvement of wind turbines construction characteristics and their prices have decreased. As an illustration of that, Figure 4 shows a constant increase in size (rotor diameter and hub height) and the power of wind turbines during the period 1998. - 2009, [7].

According to the statistical data, the average installed power of an individual wind turbine in the year 2010 in Germany was 2,057 MW, [8].

Special attention is nowadays paid to those elements of wind turbines that showed certain shortcomings during the previous period, i.e. transmission mechanisms, generators, blades, etc. The availability of the present wind turbines is $98 \%$, the level of utilisation is constantly increased, as well as the 
economic life with the modern machines that are nowadays projected for 25-year time period.
Certainly, all this is thanks to the 20 -year operational experience in this field.

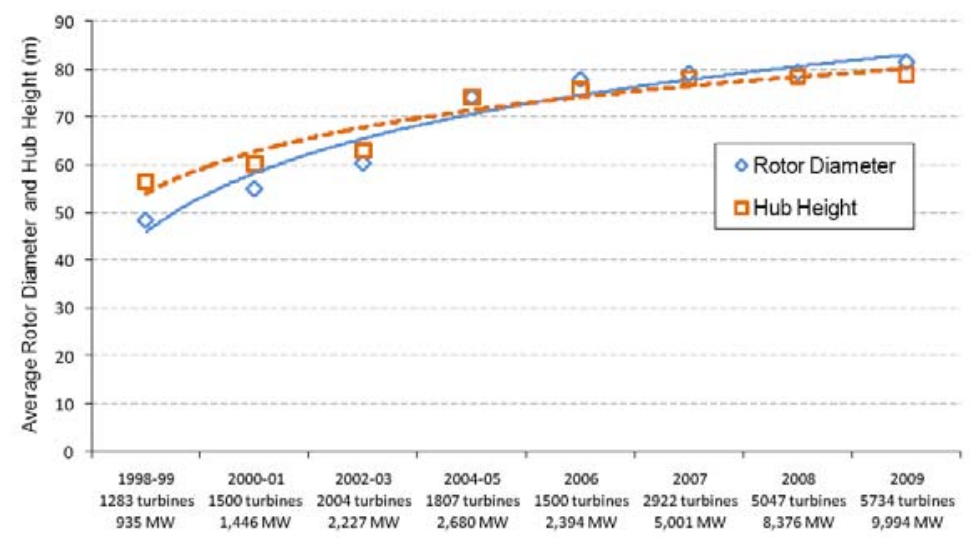

Figure 4. Increase in rotor diameter and hub height

There is a huge number of wind turbine manufacturers in the world today. There are certainly both a lot of similarities and differences between them. A few years ago $70 \%$ of wind turbines in the world were produced by the European companies. As two typical representatives of this concept of the development of wind turbines, two companies specialised in that production have imposed themselves: Vestas and Enercon. A share of these companies in the world's production of wind turbines ranged from $28.4 \%$ and $13.4 \%$ in 2005 , through $20.3 \%$ and $12.5 \%$ in 2007 to $17.8 \%$ and $9 \%$ in 2008 , respectively, $[9,10,11]$. That ,decrease" may first of all be explained by the expansion of RES market, i.e. of wind farms in the other areas in the world. Namely, it is indicative that the companies in those countries where big capacities are being installed have increased their share (e.g. in USA "GE Energy" to $16.7 \%$, in China „Sinovel” to $4.5 \%$ ).

\section{PRICE AND COSTS}

It is noteworthy here that it is very difficult to make a comparison between different technologies for generation of electricity, especially these from RES, and the „conventional” ones. Nevertheless, it can be concluded that the price of electricity generated from wind farms becomes more and more comparable with the price of electrical energy produced from „,conventional” fossil fuels. However, the only case where they are completely comparable are the wind parks that are located at places with excellent wind characteristics.
Fig. 5 shows average values of the price of electricity produced in wind farms during the period 1999-2009, [7]. As presented in the diagram in Fig. 5 , the data relate to a different number of projects (from 7 to 180) and different number of installed capacities (from $450 \mathrm{MW}$ to $12813 \mathrm{MW}$ ).

Due to the intensifying installation of wind farms and the use of state-of-the-art technology in the past few years, discussed above in this paper, at the beginning of 2006, the wind turbines got even more expensive, which, due to the big influence on the overall cost, also increased the cost of electricity produced in wind parks, Figure 5.

It is difficult to make a realistic forecast of the movement of prices in the future period for the wind farms, as this involves many influencing factors; it is especially difficult to make their comparison with fossil fuels. However, there are a lot of such forecasts that are more than optimistic, [12-14].

\section{SPECIFIC FEATURES OF RESEARCH}

Because of the need to install wind farms on complex terrains and in specific wind conditions, there is a requirement to have special research in these circumstances, and consequently, a special analysis of behaviour of the selected equipment in these conditions.

There is currently an intensive work underway on new construction designs. As one of the examples we can state a new offshore wind turbine of the Danish company „Vestas” V164 7 MW, that has a 164 m diameter rotor, which means that it has a size of over 21 $000 \mathrm{~m}^{2}$ (almost like three football fields), [15]. 
„Direct drive" wind turbines present another special example; their biggest manufacturer is German „Enercon”. They have a number of advantages compared to conventional wind turbines (e.g.: fewer parts, easier maintenance, simpler installation, etc.), however, they have some drawbacks, too. Their program also includes the development of a prototype of machine of $6 \mathrm{MW}$ with rotor diameter of $114 \mathrm{~m}$ and the rotational speed of 8-13 rpm, [16].
One of the possible solutions that has been subject of intensive work in the past years is a shrouded wind turbine, in Fig 6, that would be much more efficient than the present ,conventional” water turbines.

Either way, it will certainly take a number of years before the new construction designs are put to commercial production.

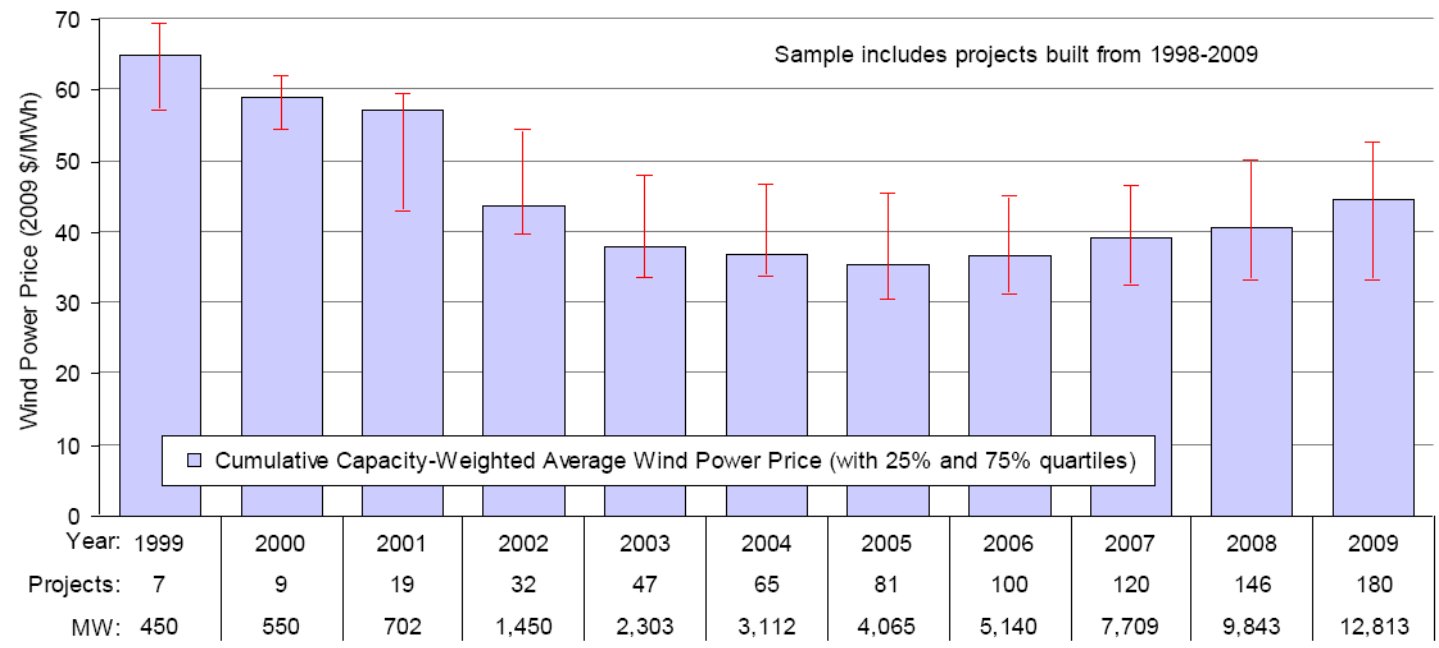

Figure 5. Average values of electricity produced in wind farms

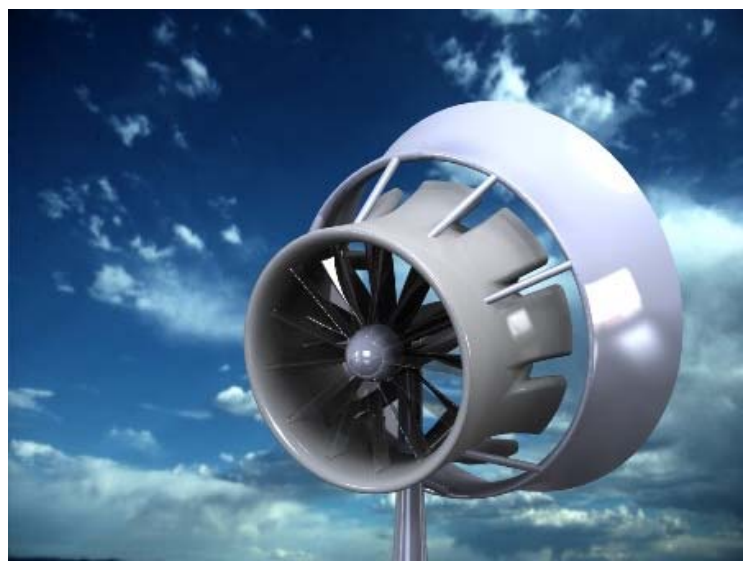

Figure 6. Shrouded wind-turbine [17]

\section{CONCLUSION}

The wind energy has had very powerful development and this has been particularly the case in the past 20 years. From everything stated above and having analysed the development and the perspectives of wind energy technology, it is evident that the wind farms are becoming a significant source of production of electricity and that they also represent a significant contribution when it comes to meeting the obligations of the countries signatories of the Kyoto protocol on reduction of greenhouse gas emissions.

According to the estimates, we are yet to see the best of the wind energy. Further improvement of wind turbine production technology depends on a number of factors. Most important among them include an increase of market, which will further enable enhancement of knowledge and experiences in the field of using the wind energy for electricity 
generation, as well as inclusion of a larger number of specialised experts, scientific and other institutions into these interdisciplinary problems. The main challenges that are posed are decreasing the cost of wind turbine production and increasing their efficiency.

Potentials and possibilities are one thing and accomplished results are another. One way or another, political support based on real potentials plays a very important role, which is not quite satisfactory at the moment.

Therefore, one may conclude that all the forecasts about the wind farms are realistic, although they differ in their values.

\section{REFERENCES}

[1] European Parliament, Directive 2001/77/EC, Renewable Energy: The Promotion of Electricity From Renewable Energy Sources (2001), $\mathrm{http} / /$ /europa.eu/legislation_summaries/energy/renewable_en ergy/127035 en.htm

[2] http://www.gwec.net (2010)

[3] S. Krohn, P. E. Morthorst, S. Awerbuch, A report by the European Wind Energy Association, articles of the EWEA, available at www.ewea.org/fileadmin/ewea_documents/documents/publicati ons/reports/Economics_of_Wind_Main_Report_FINAL-Ir.pdf

[4] United Press International, China Increases Its Wind Power (Beijing, January 19, 2009), web site www.upi.com/Energy_Resources/2009/01/19/China_increases_i ts_wind power/UPI-58981232388248.

[5] Recharge, China Boosts Wind Power Target to 100GW by 2020 (May 5, 2009), web site www.rechargenews.com/regions/asia_pacific/article 177459.ece.

[6] http://www.gwec.net/index.php?id=168. (2010) [7]

http:/www.eia.gov/neic/speeches/howard052510.pdf

[8] C. Ender, Wind Energy Use in Germany -

Status 31.12.2010, DEWI journal 38 (2011) 36-48.

[9] C. Ender, International Development of Wind Energy Use - Status 31.12.2005, DEWI journal 29 (2006) 38-44.

[10] C. Ender, International Development of Wind Energy Use - Status 31.12.2007, DEWI journal 33 (2008) 43-53.

[11] C. Ender, International Development of Wind Energy Use - Status 31.12.2008, DEWI journal 35 (2009) 28-33.

[12] G. Van Kuik, B. Ummels, R. Hendriks, Perspectives of Wind Energy, Proceedings of International Conference Advances in New and Sustainable Energy Conversion and Storage Technologies, Dubrovnik, Croatia 2006, 61-79.

[13] International Energy Agency, World Energy Outlook 2009 (Paris, France, November 2009), p. 128.

[14] International Energy Outlook (2010), U.S. Energy Information Administration, Office of Integrated Analysis and Forecasting, U.S. Department of Energy, http://www.eia.gov/oiaf/ieo/index.html

[15] http://www.vestas.com/en/wind-powerplants/procurement/turbine-overview/v164-7.0-mwoffshore.aspx\#/vestas-univers (July 2010)

[16] http://www.enercon.de. (July 2010) [17]

http://www.flickr.com/photos/mass_cec/5762452246/

\section{СТАҢЕ, ПЕРСПЕКТИВЕ И СПЕЦИФИЧНОСТИ ЕНЕРГИЈЕ ВЈЕТРА У 2011.}

Апстракт: Добијање електричне енергије из енергије вјетра старо је преко 100 година. Вјетроелектране данас представљају значајан извор у производњи електричне енергије. Континуално се повећава њихова величина, снага, побољшавају се њихове радне карактеристике, карактеристике прикључења и рада у мрежи, развија ce offshore тржиште итд. Различите процјене, засноване на одређеним циљевима и могућностима, указују на њихову још значајнију улогу у будућности. Међутим, за остваривање ових циљева потребно је осигурати још низ претпоставки. У овоме раду дат је приказ тренутног стања и перспектива производње електричне енергије из вјетроелектрана у свијету, са неким својим специфичностима.

Кључне ријечи: енергија вјетра, стање, перспективе, специфичности 